\title{
Investigations on Performance and Emission Characteristics of Diesel Engine with Biodiesel (Jatropha Oil) and Its Blends
}

\author{
Amar Pandhare ${ }^{1}$ and Atul Padalkar ${ }^{2}$ \\ ${ }^{1}$ Department of Mechanical Engineering, Smt. Kashibai Navale College Of Engineering, Pune, Maharashtra 411041, India \\ ${ }^{2}$ Flora Institute of Technology, Pune, Maharashtra 411041, India
}

Correspondence should be addressed to Amar Pandhare; amarppandhare@gmail.com

Received 25 December 2012; Revised 4 February 2013; Accepted 10 February 2013

Academic Editor: Nuri Azbar

Copyright (C) 2013 A. Pandhare and A. Padalkar. This is an open access article distributed under the Creative Commons Attribution License, which permits unrestricted use, distribution, and reproduction in any medium, provided the original work is properly cited.

\begin{abstract}
This paper presents the performance of biodiesel blends in a single-cylinder water-cooled diesel engine. All experiments were carried out at constant speed $1500 \mathrm{rpm}$ and the biodiesel blends were varied from B10 to B100. The engine was equipped with variable compressions ratio (VCR) mechanism. For 100\% Jatropha biodiesel, the maximum fuel consumption was $15 \%$ higher than that of diesel fuel. The brake thermal efficiency for biodiesel and its blends was found to be slightly higher than that of diesel at various load conditions. The increase in specific fuel consumption ranged from $2.75 \%$ to $15 \%$ for B10 to B100 fuels. The exhaust gas temperature increased with increased biodiesel blend. The highest exhaust gas temperature observed was $430^{\circ} \mathrm{C}$ with biodiesel for load conditions $1.5 \mathrm{~kW}, 2.5 \mathrm{~kW}$, and $3.5 \mathrm{~kW}$, where as for diesel the maximum exhaust gas temperature was $440^{\circ} \mathrm{C}$. The $\mathrm{CO}_{2}$ emission from the biodiesel fuelled engine was higher by $25 \%$ than diesel fuel at full load. The CO emissions were lower with Jatropha by $15 \%, 13 \%$, and $13 \%$ at $1.5 \mathrm{~kW}, 2.5 \mathrm{~kW}$, and $3.5 \mathrm{~kW}$ load conditions, respectively. The $\mathrm{NO}_{x}$ emissions were higher by $16 \%, 19 \%$, and $20 \%$ at $1.5 \mathrm{~kW}, 2.5 \mathrm{~kW}$, and $3.5 \mathrm{~kW}$ than that of the diesel, respectively.
\end{abstract}

\section{Introduction}

Diesel engines have provided power units for road transportation systems, ships, railway locomotives, equipment used for farming, construction, and in almost every type of industry due to its fuel efficiency and durability. However, Diesel engines are the major sources of $\mathrm{NO}_{x}$ and particulate matter emissions which are environmental concerns. For automotive industry the reduction of $\mathrm{NO}_{x}$ and PM emission is the most important task. National governments are imposing stringent emissions on automotive sector to reduce $\mathrm{NO}_{x}$ and $\mathrm{PM}$ emissions. Also global house warming gases (GHG) are going to receive more focus from future autosector. Therefore, the stringent emission regulation requirements give a major challenge to comply emission targets while maintaining its performance, drivability, durability, and fuel economy. The use of alternative fuels for internal combustion engines has attracted a great deal of attention due to fossil fuel crisis and also GHG impact. Alternative fuels should be easily available, environment friendly, and technoeconomically competitive. Successful alternative fuel should fulfill environmental and energy security needs without sacrificing engine operating performance [1]. Renewable resources offer the opportunity to tap local resources and reduce dependency on fossil energy resources. Most biodiesel oils, particularly of the nonedible type can be used as fuel in diesel engines. They contain significant amount of oxygen $[2,3]$. The idea of using vegetable oils as fuel for diesel engine is not new. When Rudolf diesel invented diesel engine and demonstrated in the 1900 world exhibition in Paris, using peanut oil and presented that "The use of vegetable oils for engine fuels may seem insignificant today, but such oils may become in course of time as important as petroleum and coal tar products of present times" [4].

One of the promising alternative fuel considered for diesel engine is biodiesel. Biodiesel fuels are renewable, as the carbon released by the burning of biodiesel fuel is used when the oil crops undergo photosynthesis. Biodiesel also offers the advantage of being able to readily use in existing diesel engines without engine modifications [5-9]. Eventhough biodiesel has many advantages, because of engine problems its use is restricted to maximum $20 \%$ only $[10,11]$. Also when 
Table 1: Properties of diesel and Jatropha oil.

\begin{tabular}{lcc}
\hline Properties & Diesel & Jatropha oil \\
\hline Density $\left(\mathrm{kg} / \mathrm{m}^{3}\right)$ & 840 & 918 \\
Viscosity $(\mathrm{cSt})$ & 9.59 & 49.9 \\
Calorific value $(\mathrm{kJ} / \mathrm{kg})$ & 42,390 & 39,774 \\
Flash point $\left({ }^{\circ} \mathrm{C}\right)$ & 75 & 240 \\
Cetane number & $45-55$ & 45 \\
Carbon residue $(\%)$ & 0.1 & 0.44 \\
\hline
\end{tabular}

TABLE 2: Engine specifications.

\begin{tabular}{lc}
\hline Parameter & Specifications \\
\hline Engine type & 4-stroke, water-cooled, single-cylinder \\
Bore $(\mathrm{mm})$ & 87.5 \\
Stroke $(\mathrm{mm})$ & 110 \\
Compression ratio & $17.5: 1$ \\
Rated power $(\mathrm{kW})$ & 3.5 \\
Cooling fluid & Water \\
Number of cylinders & One \\
\hline
\end{tabular}

biodiesel is used as fuel in existing engines, there is decrease in power, drop in thermal efficiency, increase in specific fuel consumption, and higher $\mathrm{NO}_{x}$ emissions [12-15]. In order to overcome these problems various modifications in engine operating parameters are suggested. The various modifications suggested are varying the compression ratio [16-18], injection pressure [19-21], use of multiple injections, oil preheating, and so forth [22-24]. Table 1 presents the comparison of properties of diesel and biodiesel (Jatropha).

\section{Present Work}

Present research work has been focused to investigate the effect of compression ratio and injection pressure on the performance, emissions, and combustion parameters of Jatropha blended fuelled engine. Experiments were conducted at different compression ratios and different injection pressures. All experiments are carried out on a single-cylinder diesel engine used for agriculture purposes and at a constant speed of $1500 \mathrm{rpm}$. The experimental results of thermal efficiency, $\mathrm{HC}, \mathrm{CO}, \mathrm{NO}_{x}$, smoke opacity, $\mathrm{BP}$, and thermal efficiency were analyzed at various loads points of $25 \%, 50 \%, 75 \%$, and $100 \%$.

\section{Experimental Setup and Experiments}

A typical $3.5 \mathrm{~kW}$ single-cylinder 4-stroke water-cooled diesel engine at $1500 \mathrm{rpm}$ was used for the research work, and Table 2 presents engine specifications.

The schematic diagram of the experimental set up is shown in Figure 1. An eddy current dynamometer was used for load control on the engine. The piezoelectric pressure transducer was mounted on cylinder head. Various thermocouple temperature sensors were installed at appropriate locations to measure water inlet and outlet, manifold air temperature, exhaust outlet, and heat exchanger outlet temperatures. A temperature thermocouple was installed on the surface of high pressure fuel pipe. A precision crank angle encoder was coupled with the main shaft of the engine. Two openings were made in exhaust gas pipeline for sampling purposes. Fuel metering was done using a burette fitted with a three-way valve measuring unit installed on fuel tank as shown in Figure 1. The mass flow rate of intake air was measured with an orifice meter connected to a manometer. A surge tank was used to damp out the pulsations produced by the engine, for ensuring a steady flow of air through the intake manifold. An AVL 444 Di gas analyzer was used for measuring the $\mathrm{CO}, \mathrm{HC}$, and $\mathrm{NO}_{x}$ emissions and the smoke density was measured using AVL 437 smoke meter.

The engine was warmed up prior to data acquisition. All the engine test runs were carried out in fair constant ambient conditions. During the tests with Jatropha biodiesel, the engine was started with diesel until it was warmed up and then fuel was switched to various diesel-biodiesel blends. After finishing the tests with diesel-biodiesel blends, the engine was always switched back to diesel fuel and the engine was run until the biodiesel had been purged from the fuel line, injection pump, and injector. This was done to prevent starting difficulties at the later time. Initially the test engine was operated with base fuel diesel for about 10 minutes to attain the normal working temperature conditions. After that the baseline data was generated and the corresponding results were obtained.

The engine was then operated with blends of Jatropha biodiesel and diesel, namely, B5, B10, B20, B40, B60, B80, and $B 100$. At every operation the engine speed was checked and maintained constant. All the measurements were repeated five times, and the arithmetic mean of these five readings was employed for calculation and analysis. The different performance and emission parameters analyzed in the present investigation were brake thermal efficiency (BTE), brake specific fuel consumption (BSFC), exhaust gas temperature (EGT), carbon monoxide (CO), unburned hydrocarbons (UHC), nitrogen oxides $\left(\mathrm{NO}_{x}\right)$, and smoke opacity. For baseline data, the engine compression ratio was set to 17.5 and fuel injection pressure $\left(P_{\text {inj }}\right)$ was maintained at 180 bar. Then compression ratio was increased from 17.5 to 19.5 in the step of 1 and fuel injection pressure was varied from 180 bar to 220 bar in the step of 20 bar.

\section{Results and Discussion}

4.1. Emissions for Biodiesel Blends. Figure 2 shows the variation in smoke opacity for all biodiesel blends at various load points. The smoke opacity was reduced in the range from $19.4 \%$ to $44.4 \%$ for various biodiesel blends as compared to that of diesel. This was mainly due to complete combustion, as additional oxygen is available from fuel itself. The smoke opacity increases with increase in engine loads. As the blend concentration was increased, smoke also increased even at lower loads and was higher than mineral diesel. This is due to poor atomization of Jatropha oil. Heavier fuel molecules, higher viscosity, and low volatility result in poor atomization of fuel. Figure 3 shows the variation in $\mathrm{NO}_{x}$ emission at various load points and for various biodiesel blends. $\mathrm{NO}_{x}$ 


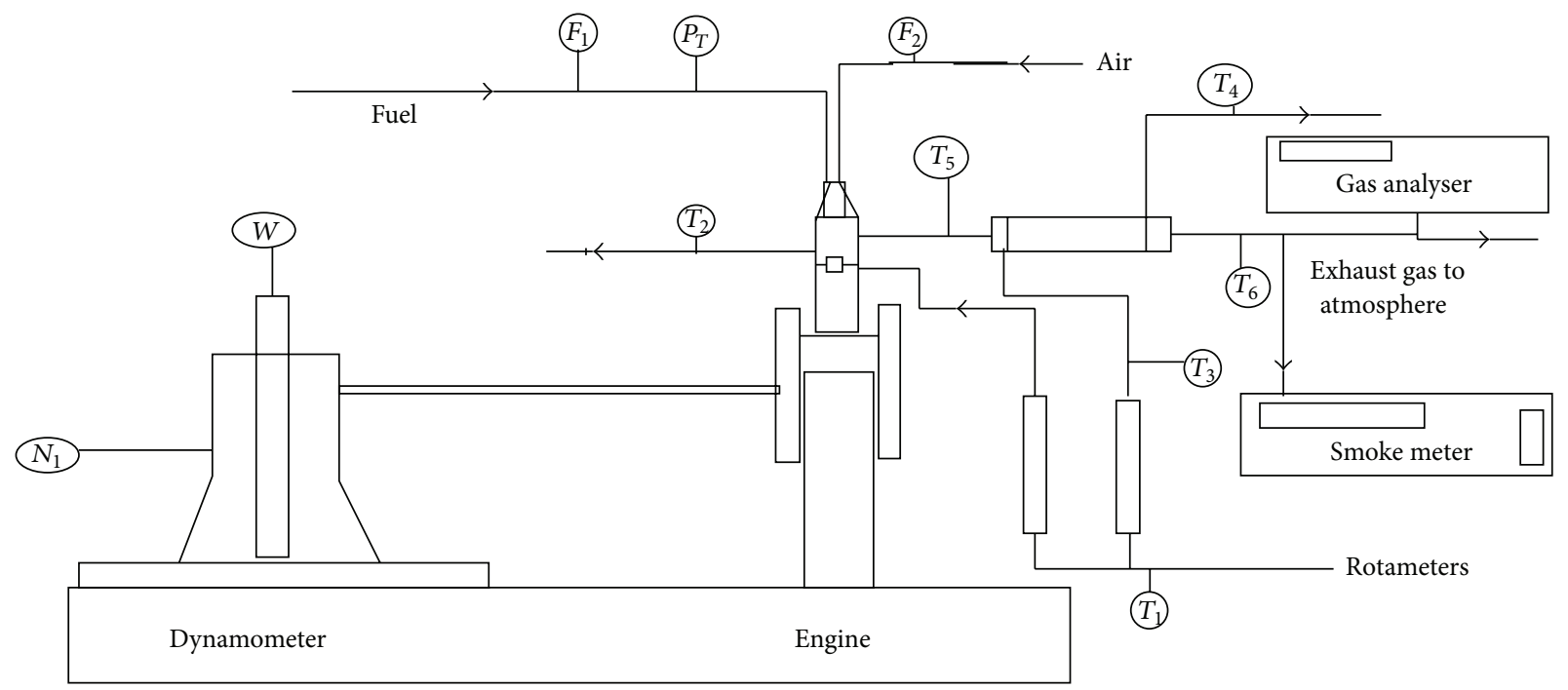
$F_{1}, F_{2}:$ Flow sensors
$T_{1}-T_{6}:$ Temperature sensors
$P_{T}$ : Cylinder and injection pressure sensor
$N$ : Engine speed sensor

$W$ : Load sensor

FIGURE 1: The schematic diagram of the experimental setup.

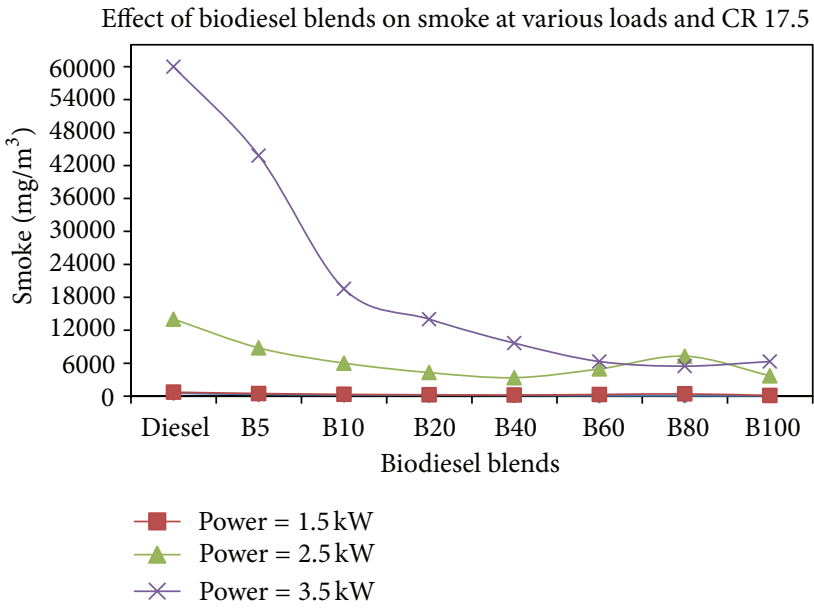

FIGURE 2: Variation in smoke opacity for various biodiesel blends at different loads.

was increased in the range from $2.6 \%$ to $16.2 \%$ for various biodiesel blends for no load to full load as compared to diesel. As the engine load is increased, the mass emission of $\mathrm{NO}_{x}$ reduces. The most important factor for the formation of $\mathrm{NO}_{x}$ is the combustion temperature in the cylinder and the availability of oxygen. The Jatropha oil has considerable higher viscosity which results into longer combustion duration and demonstrates significant energy release during the last phase of burning. Figures 4 and 5 show the variation of $\mathrm{CO}$ and THC emission trends at various loads for biodiesel blends. Continuous reduction in $\mathrm{CO}$ was observed at $0.5 \mathrm{~kW}, 1.5 \mathrm{~kW}$, $2.5 \mathrm{~kW}$ load whereas at $3.5 \mathrm{~kW}$ load and B20 blends onwards $\mathrm{CO}$ emission was increased. Increase in THC emissions was

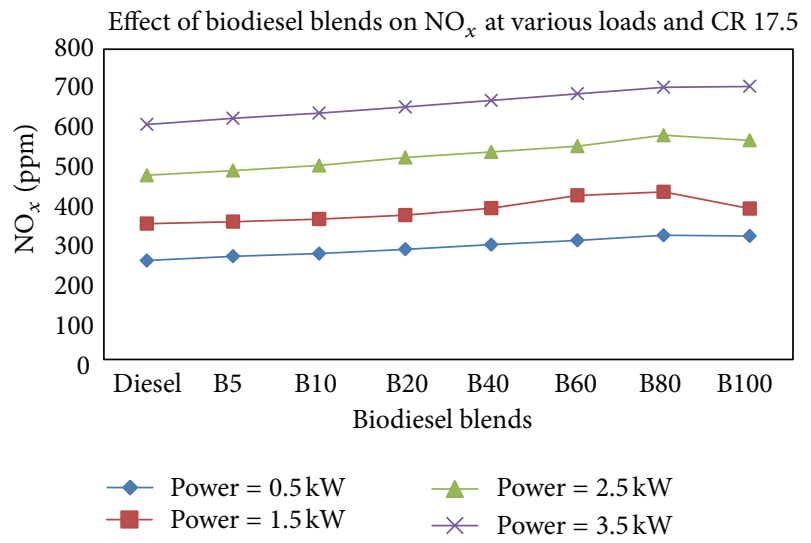

FIGURE 3: Variation in $\mathrm{NO}_{x}$ for various biodiesel blends at different loads.

noticed at full load point with increased biodiesel blends. CO emissions were reduced by $4 \%$ to $9.33 \%$ for various biodiesel blends, respectively, at full load. THC emission was reduced by $4.1 \%$ and $6.66 \%$ for B5 and B10 blends and then was increased for B20 to B100 blends. With increased Biodiesel blends, the energy content in the fuel reduces and to get same power, more quantity of fuel needs to be injected and there are chances of wall wetting and fuel trapped in crevices zones causes more THC emissions. Blends higher than 20\% showed higher $\mathrm{CO}$ emissions than diesel fuel at high engine load. Due to higher viscosity, the air fuel mixing process is affected by the difficulty in atomization and vaporization of Jatropha oil blends. The resulting locally rich mixtures 


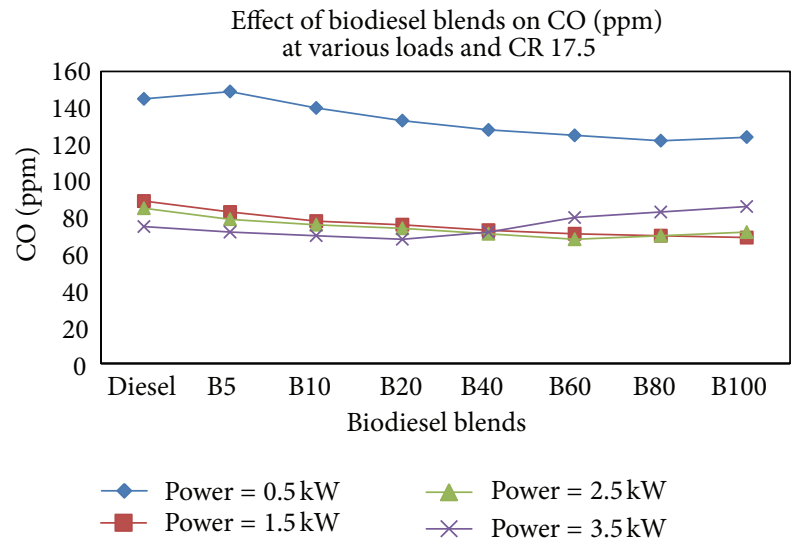

FIGURE 4: Variation in CO for various biodiesel blends at different loads.

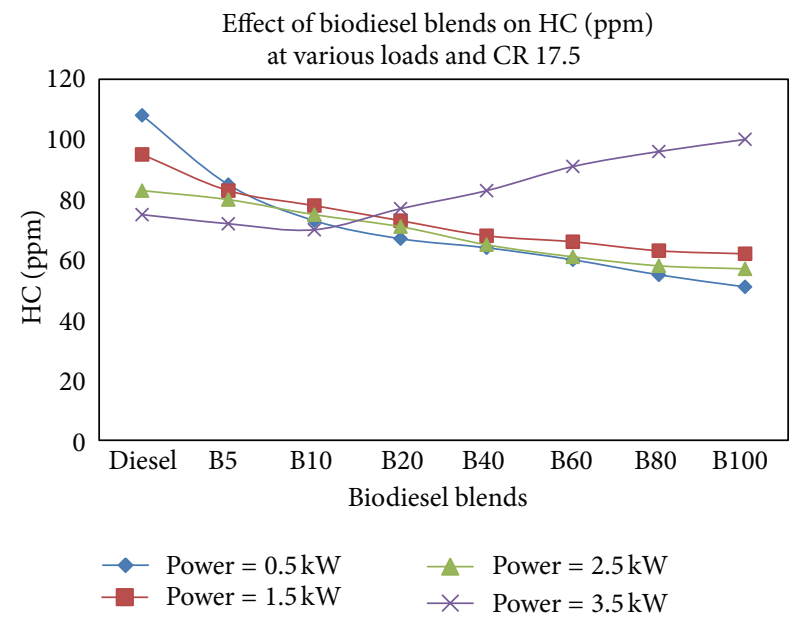

FIGURE 5: Variation in HC for various biodiesel at different loads.

cause more incomplete combustion products such as $\mathrm{CO}$ and HC.

4.2. Engine Performance for Biodiesel Blends. The engine performance indicators considered were brake specific fuel consumption (BSFC), brake thermal efficiency (Bth) and exhaust gas temperature. Figure 6 shows the BSFC plots for various biodiesel fuel blends at all loads points. Brake specific fuel consumption is a measure of volumetric fuel consumption for any particulate fuel. Diesel fuel had the lowest BSFC throughout the tests. BSFC increased in the range from $2.26 \%$ to $13.58 \%$ for various biodiesel blends, respectively, than that of diesel. The increase in BSFC for the biodiesel blends may be due to biodiesels having less energy content (lower heating value) than the diesel. The higher the biodiesel content in the blend and the lower their heating values result in higher BSFC. Figure 7 shows variation in thermal efficiency for biodiesel. It was observed that for all the loads, the diesel fuel showed higher thermal efficiency as compared with blends. The thermal efficiency was decreased

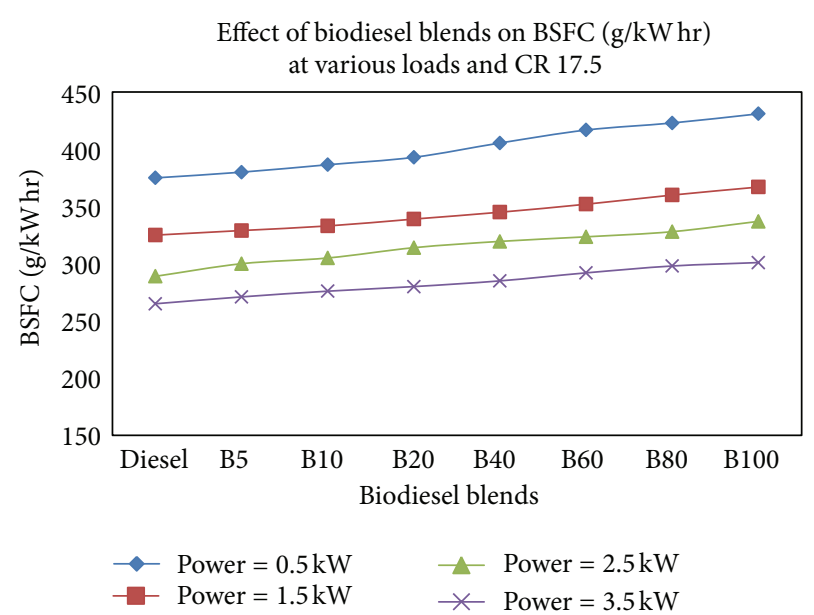

FIGURE 6: Variation in BSFC for various biodiesel blends at different loads.

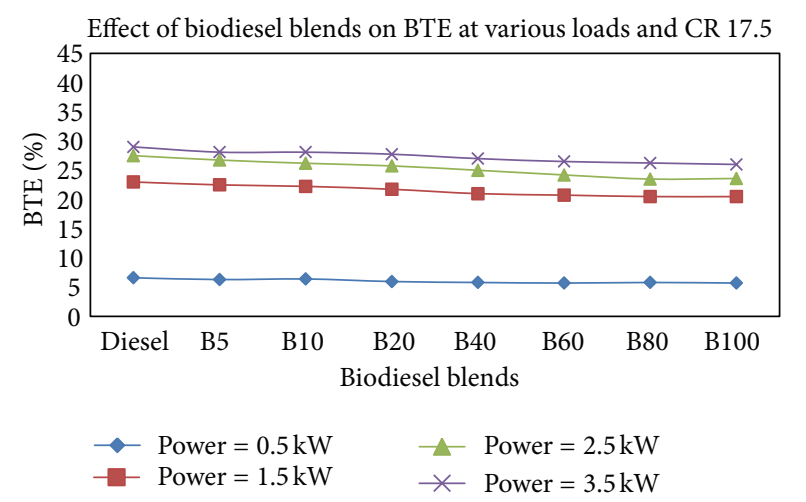

FIGURE 7: Variation in BTE for various biodiesel blends at different loads.

by $3.10 \%$ to $10.34 \%$ for various biodiesel blends, respectively, than that of diesel from no load to full load condition.

Figure 8 shows the effect of exhaust gas temperature on diesel-biodiesel blends at $1500 \mathrm{rpm}$. The results showed that the exhaust gas temperature increased with increase in load. This is due to the poor combustion characteristics of the Jatropha curcas oil because of its high viscosity. The combustion characteristics of the blends were improved by increasing the percentage of diesel fuel in the biodiesel fuel. All the test fuels exhibited lower exhaust gas temperature as compared to diesel fuel and this phenomenon can be understood that poor BSFC can be because of poor combustion efficiency.

\section{Variation in Compression Ratio}

5.1. Brake Thermal Efficiency (BTE) and Brake Specific Fuel Consumption (BSFC). Figure 9 shows the effect of compression ratio for various biodiesel blends at $3.5 \mathrm{~kW}$ load. As the compression ratio was increased from 17.5 to 19.5 it was observed that the brake thermal efficiency increased in the range from $6.76 \%$ to $7.40 \%$ for different biodiesel blends. The increase in BTE can be attributed to reduction in heat loss and 


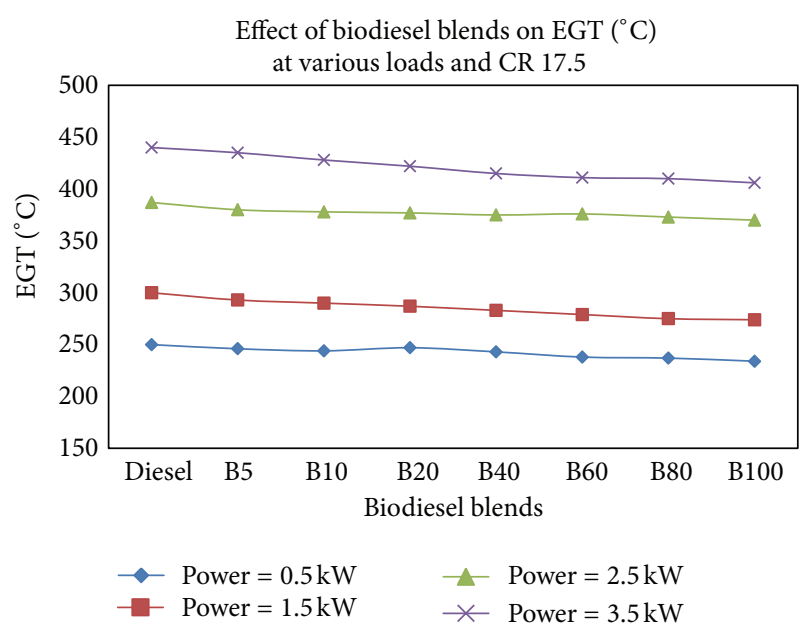

FIGURE 8: Variation in EGT for various biodiesel blends at different loads.

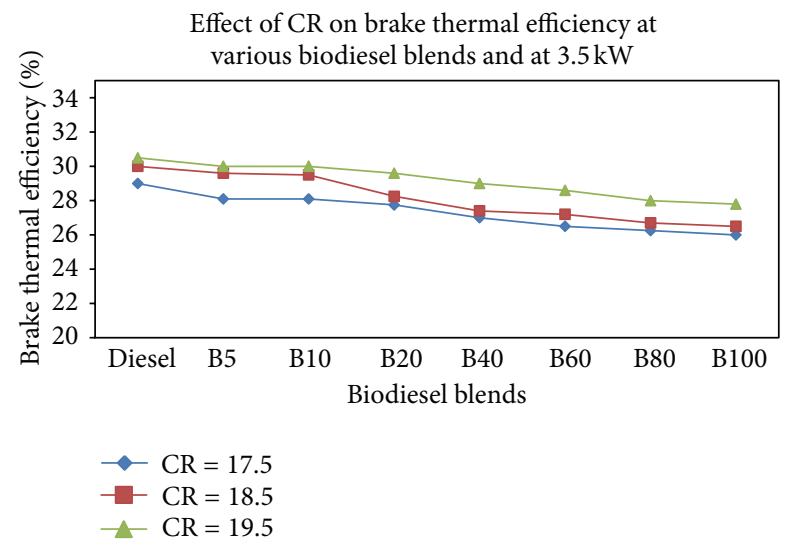

FIGURE 9: Variation in BTE for various blends at compression ratios $17.5,18.5$, and 19.5 .

increase in power with increase in load. Figure 10 shows the variation of BSFC trend with respect to compression ratios for various biodiesel blends. The results showed that as CR increased from 17.5 to 19.5 , the BSFC decreased in the range from $4.79 \%$ to $9.39 \%$ for various biodiesel blends.

5.2. Smoke Opacity. Figure 11 shows the variation of smoke opacity for various biodiesel blends of exhaust gas compared with neat diesel at different compression ratios, namely, 17.5, 18.5, and 19.5. The results showed that soot emitted by all biodiesel blends is lower than diesel at all loads and compression ratios. The reduction in smoke is observed due to combustion being mixed controlled for these blends and also the fuel bounded oxygen, as is also the case for neat diesel. For compression ratio 19.5, the reduction in smoke opacities for various blends was in the range from $19.4 \%$ to $42.8 \%$ as compared to compression ratio 17.5 . The reason for this behavior was the different amount of sulphur between the diesel and biodiesel blends. Sulphur in the fuel causes

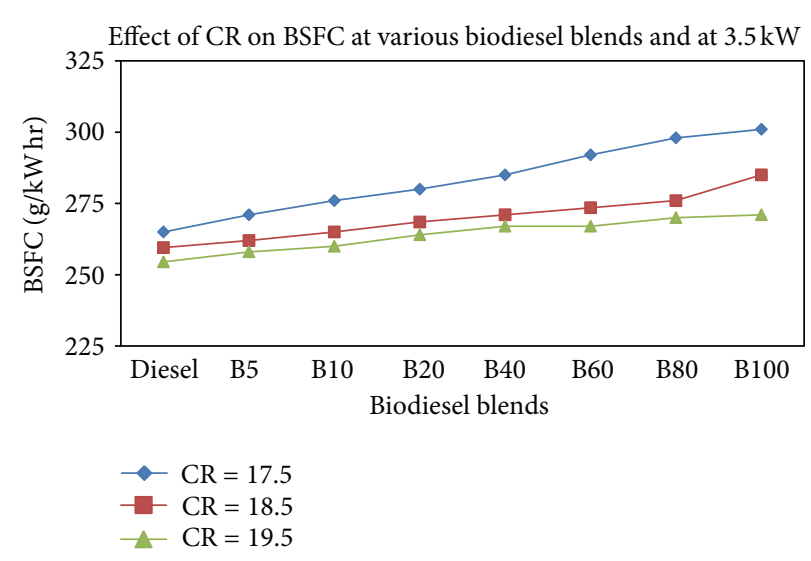

FIGURE 10: Variation in BSFC for various blends at compression ratios $17.5,18.5$, and 19.5 .

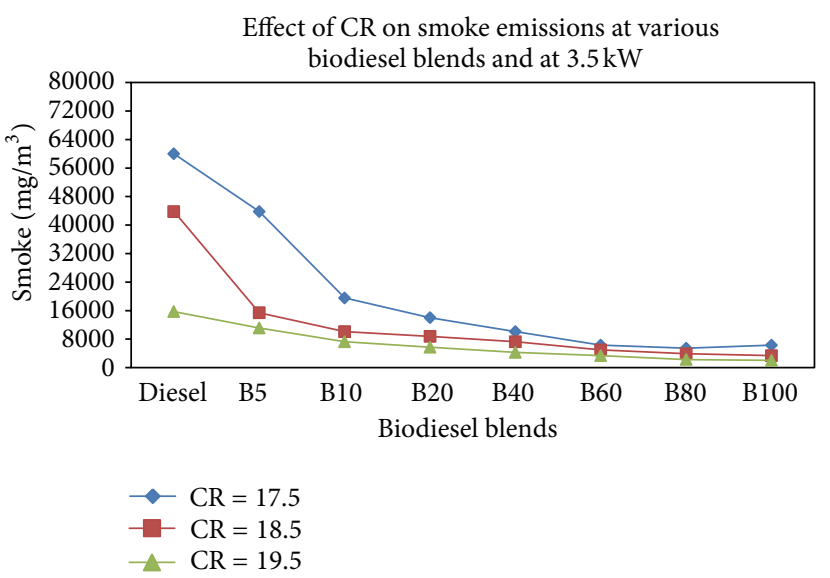

FIGURE 11: Variation in Smoke opacity for various biodiesel blends at compression ratios $17.5,18.5$, and 19.5.

formation of sulphates and increases the smoke emitted from diesel engines.

5.3. $N O_{x}$. Figure 12 shows the effect of various biodiesel blends at full load on nitric oxides $\left(\mathrm{NO}_{x}\right)$. It was observed as the percentage of Jatropha oil in biodiesel increases $\mathrm{NO}_{x}$ emission increases. The Biofuels with higher oxygen contents, $1.45 \%$ to $4.075 \%$, and neat biodiesel produce higher or a bit lower NO emissions, depending on the load. This results in lower $\mathrm{NO}$ formation rates since the combustion pressure rises more slowly, giving more time for cooling through heat transfer and dilution and leading to localized gas temperatures. By reducing aromatics the flame temperature will drop, leading to a lower NO production rate. As a result, the aromatics have high carbon-hydrogen ratios and thus fuels with lower aromatics will lead to a smaller amount of $\mathrm{CO}_{2}$ and larger amount of $\mathrm{H}_{2} \mathrm{O}$ being formed compared to high aromatic fuels. With further increase in blends, $\mathrm{NO}_{x}$ emissions were increased. $\mathrm{NO}_{x}$ emissions varied very lightly at CR 18.5 and 19.5 and at higher biodiesel blends. At higher 


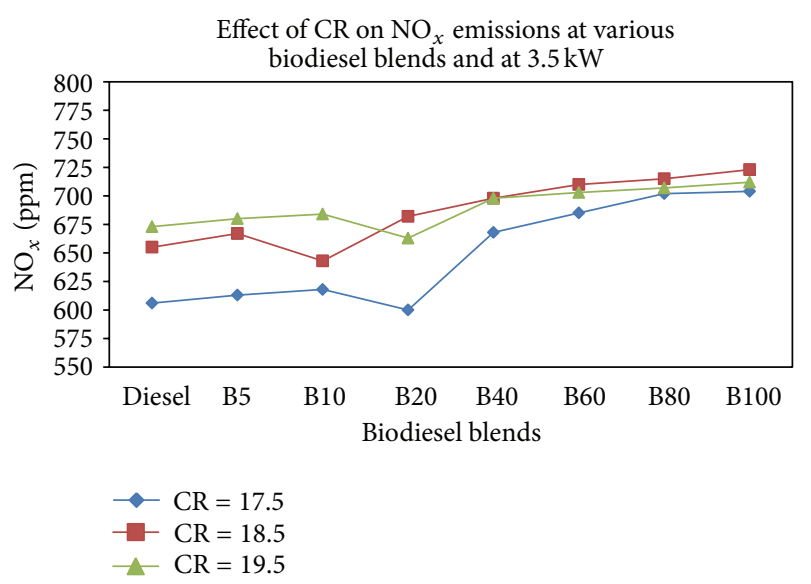

FIGURE 12: Variation in $\mathrm{NO}_{x}$ for various biodiesel blends at compression ratios 17.5, 18.5, and 19.5.

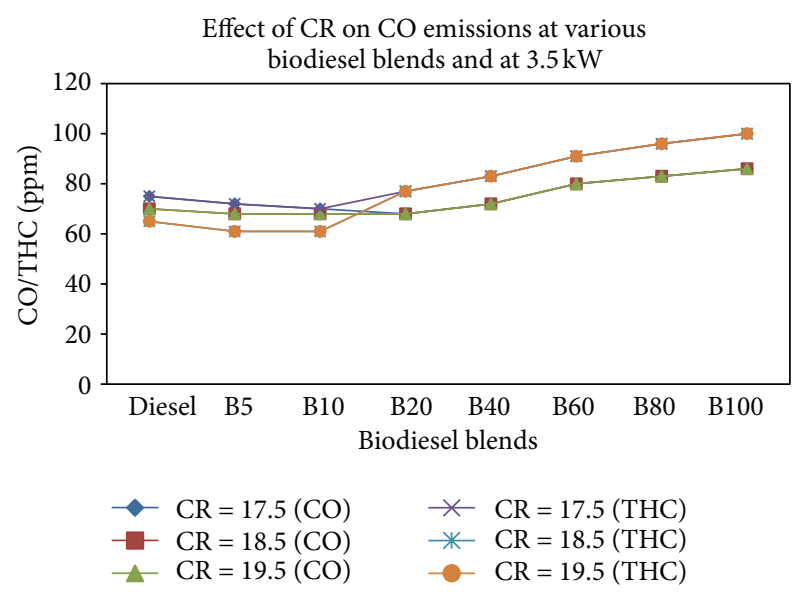

FIGURE 13: Variation in CO and THC for various biodiesel blends at compression ratios $17.5,18.5$, and 19.5 .

compression ratio $\mathrm{NO}_{x}$ is lower due to higher cetane number of the biodiesel fuel.

5.4. CO and THC. Figure 13 shows the effect of CR on the emission of unburnt hydrocarbons (HC) and carbon monoxide (CO) for all fuels blends. Figure 13 shows CO emissions decreased by $6.94 \%$ to $10 \%$ at CR 19.5 as compared with CR 17.5 for various biodiesel blends. THC emissions decreased by $11.68 \%$ to $15.27 \%$ at CR 19.5 as compared with CR 17.5 for various biodiesel blends. The plots showed increase in $\mathrm{HC}$ emissions as the quantity of diesel fuel in the blend increases.

\section{Variation in Injection Pressure}

Among several combustion parameters, fuel injection pressure is one of the important parameters which has significant role on the performance and emissions of a diesel engine. Higher injection pressures generate faster combustion rates, resulting in high cylinder gas temperatures and fuel atomization characteristics improve with higher injection pressure

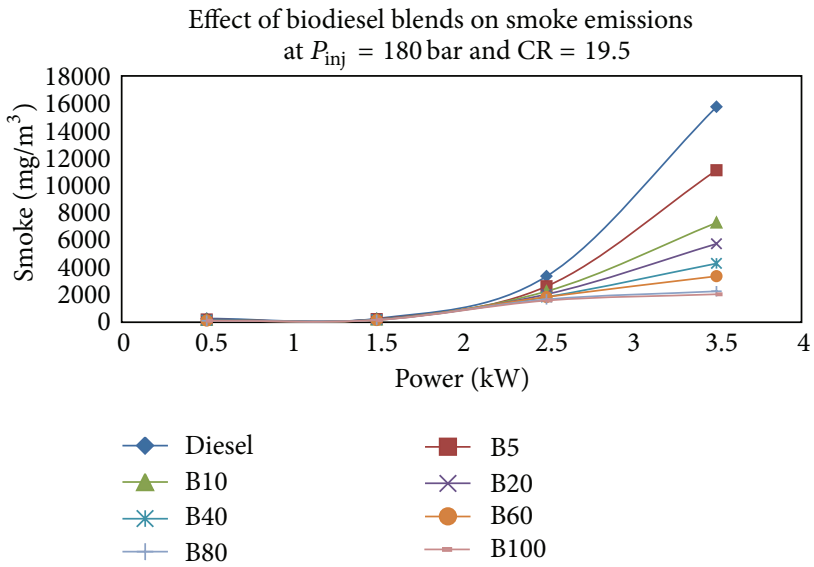

FIGURE 14: Variation in smoke opacity for various biodiesel blends at $P_{\text {inj }} 180$ bar and CR 19.5 .

so that higher surface area is exposed to the surrounding air. Detailed experimental work has been carried out to analyze the emission and performance characteristics of a single cylinder $3.5 \mathrm{~kW}$, compression ignition engine fuelled with neat diesel and biodiesel blends at fuel injection pressures of $180 \mathrm{bar}, 200 \mathrm{bar}$, and $220 \mathrm{bar}$. The tests were conducted at power $0.5 \mathrm{~kW}, 1.5 \mathrm{~kW}, 2.5 \mathrm{~kW}$, and $3.5 \mathrm{~kW}$ at constant speed. The compression ratio was adjusted to 19.5 since better engine performance was observed. The brake thermal Efficiency and brake specific fuel consumption (BSFC) are calculated and the emissions measured were carbon monoxide (CO), carbon dioxide $\left(\mathrm{CO}_{2}\right)$, hydrocarbon $(\mathrm{HC})$, and oxides of nitrogen $\left(\mathrm{NO}_{x}\right)$. Complete measurements were taken after stabilization of all operating condition at every measurement point.

6.1. Smoke Opacity. Smoke opacity was studied at various injection pressures and biodiesel blends at entire operating load region at constant speed $1500 \mathrm{rpm}$. Atomization characteristics are better at higher injection pressure which improves the air-fuel interaction. This phenomenon leads to improvement in combustion which resulted in lower exhaust smoke emissions. Figures 14, 15, and 16 shows the effect of different fuel injection pressures $180 \mathrm{bar}, 200 \mathrm{bar}$ and 220 bar, respectively, on smoke opacity from $0.5 \mathrm{~kW}$ load to $3.5 \mathrm{~kW}$ full load, respectively. It can be concluded from the results that the smoke opacity reduced with increased injection pressures which minimizes diffusion combustion. As compared to neat diesel, smoke opacity improved by $34.7 \%$ at full load when operated at 180 bar. The improvement in smoke opacity at part load region is 15 to $20 \%$ only. Continuous improvement in smoke opacity was noticed with increased blends at $P_{\text {inj }}=180$ bar. At $P_{\text {inj }}=200$ bar and $P_{\text {inj }}=$ 220 bar injection pressures, the reduction in smoke opacity was only $10 \%$ to $15 \%$ through the load regions compared to neat diesel and $100 \%$ biodiesel blend, but there was an improvement at all pressure levels with increased blends. The main reason for reduction in smoke opacity at higher blends is that the increased oxygen percentage promotes the better combustion. 


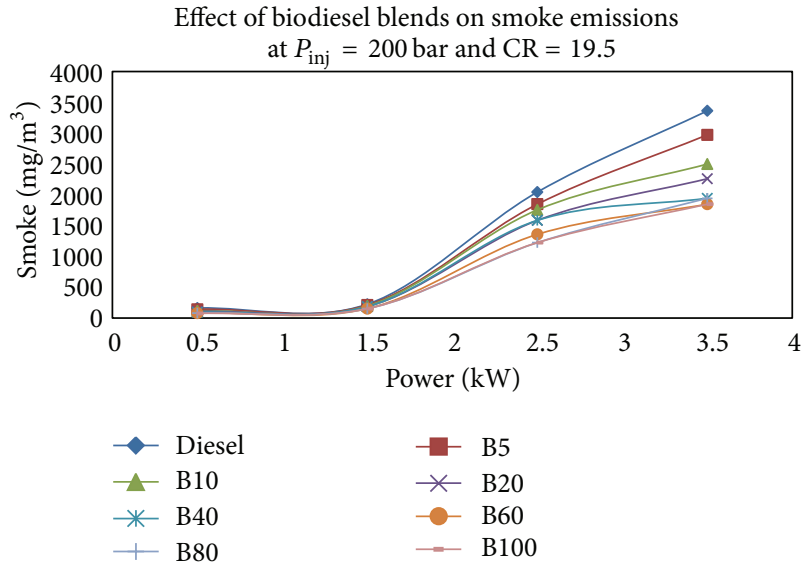

FIGURE 15: Variation in smoke opacity for various biodiesel blends at $P_{\text {inj }} 200$ bar and CR 19.5.

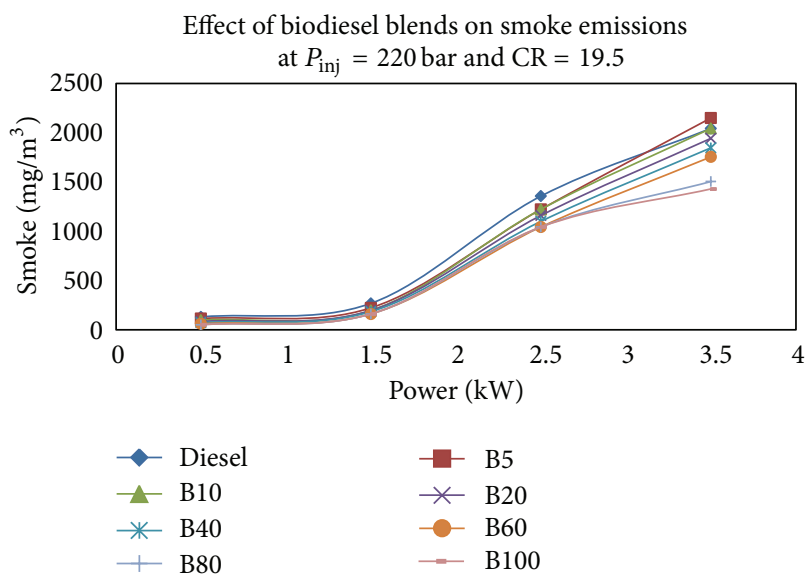

FIGURE 16: Variation in smoke opacity for various biodiesel blends at $P_{\text {inj }} 200$ bar and CR 19.5 .

\subsection{Emissions}

6.2.1. $\mathrm{NO}_{x}$ Emissions. Figures 17,18 and 19 shows the variation of $\mathrm{NO}_{x}$ emissions with different blend ratio at various load point for different Injector Opening Pressure (IOP) on research engine. $\mathrm{NO}_{x}$ emissions are increasing with increase in blend ratios for all the IOP and engine load due to increase in combustion chamber temperature. As expected $\mathrm{NO}_{x}$ level increases with increase in IOP due to faster combustion and higher temperature reached in the cycle in research. It was also observed that the $\mathrm{NO}_{x}$ emissions rise was only by $3 \%$ at low load and full load point with all biodiesel blends. But at $1.5 \mathrm{~kW}$ and $2.5 \mathrm{~kW}$ load points, the increase in $\mathrm{NO}_{x}$ was in the range from $4 \%$ to $6 \%$. Increase in $\mathrm{NO}_{x}$ emissions was observed with increased blends and load with all IOP conditions. This phenomenon was mainly due to increased in-cylinder temperature with IOP. For diesel, $\mathrm{NO}_{x}$ emissions increased from $0.4 \%$ to $1.4 \%$ when operated at 180 bar, 200 bar, and 220 bar injection pressures. It may be due to active combustion caused by smaller particles of

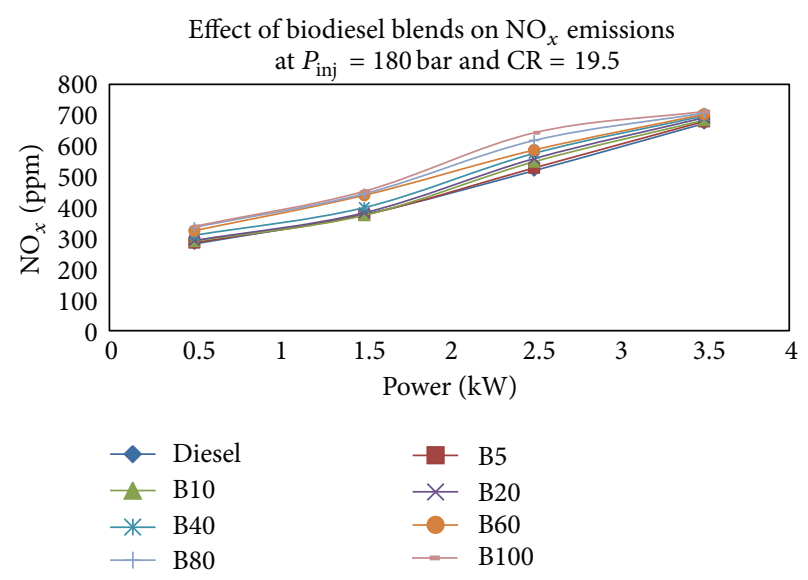

FIGURE 17: Variation in $\mathrm{NO}_{x}$ for various biodiesel blends at $P_{\text {inj }}$ 180 bar and CR 19.5 .

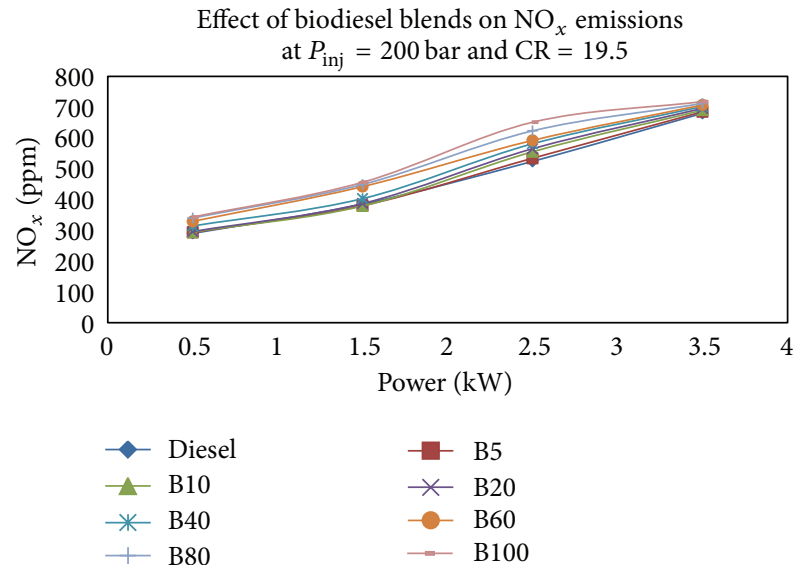

FIgure 18: Variation in $\mathrm{NO}_{x}$ for various biodiesel blends at $P_{\text {inj }}$ 200 bar and CR 19.5 .

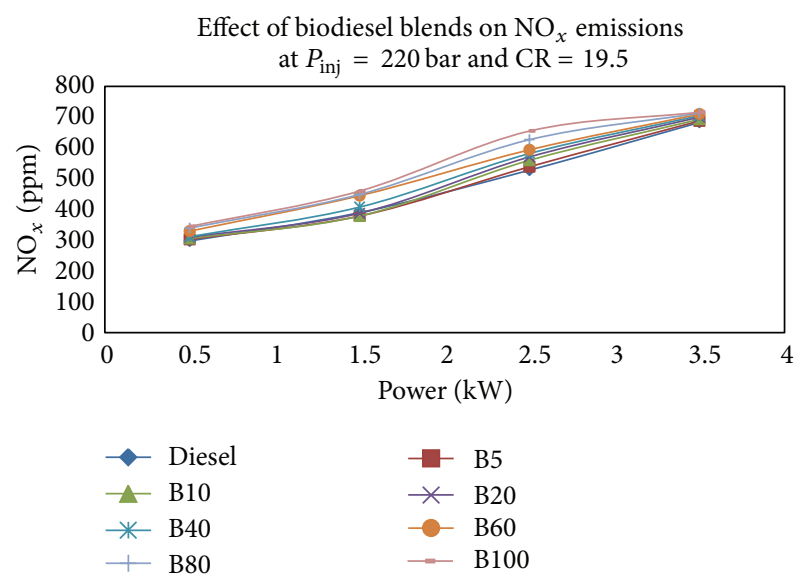

FIgURE 19: Variation in $\mathrm{NO}_{x}$ for various biodiesel blends at $P_{\text {inj }}$ 220 bar and CR 19.5. 


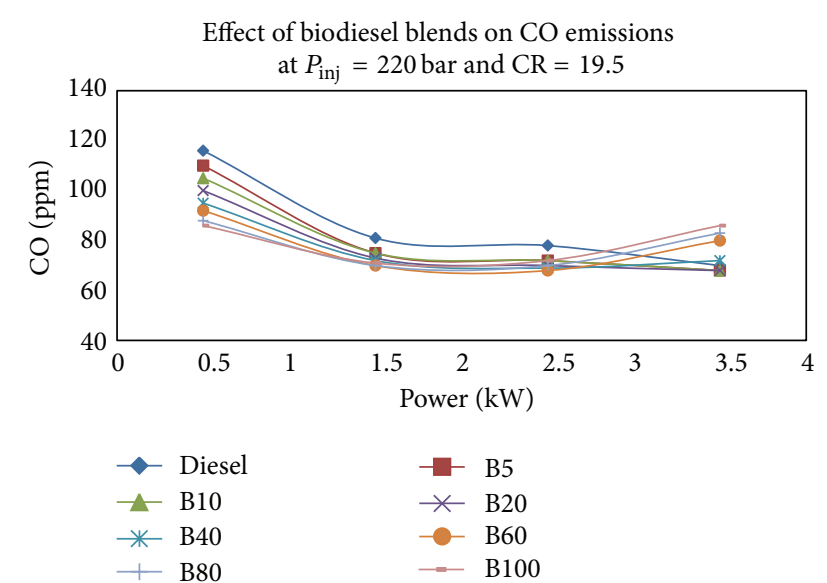

FIgURE 20: Variation in CO for various biodiesel blends at $P_{\text {inj }}$ 180 bar and CR 19.5 .

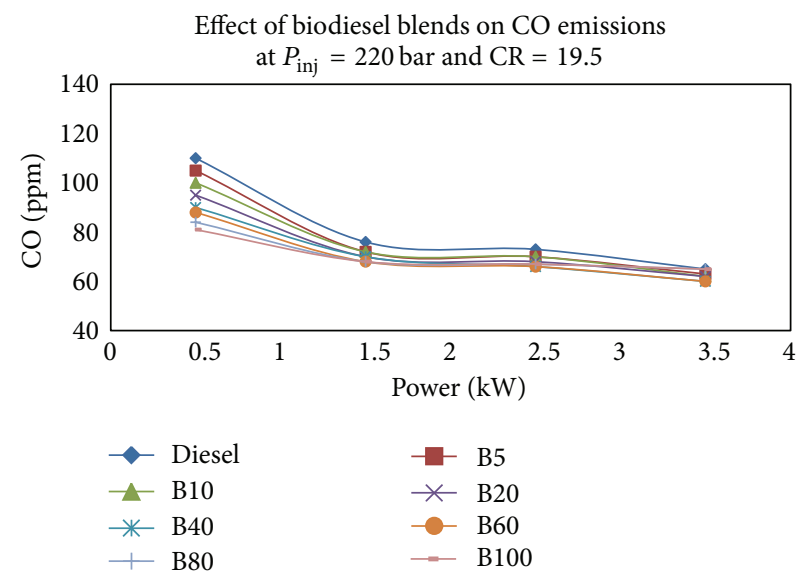

FIgure 21: Variation in CO for various biodiesel blends at $P_{\text {inj }}$ 200 bar and CR 19.5 .

atomized fuel. Similarly $\mathrm{NO}_{x}$ increased from $0.55 \%$ to $1.16 \%$ when operated from 180 bar to 220 bar injection pressure for various biodiesel blends.

6.2.2. CO and THC Emissions. Figures 20, 21, and 22 show the variation of THC and $\mathrm{CO}$ emissions with different IOPs of neat diesel, biodiesel blend fuel at $3.5 \mathrm{~kW}$ with IOPs of 180 bar, 200 bar and 220 bar. Unburnt hydrocarbons are results of incomplete combustion of fuel. With the injector opening pressure 180 bar, the UBHC and CO emissions are exceedingly higher compared to 200 bar, and 220 bar. This may be attributed to the incomplete and improper mixture formation of the fuel at lower injection pressure. However, with IOP 220 bar, the B20 fuel showed significant reduction in UBHC emissions. The improved performance was observed at IOP 220 bar with B20 fuel, though they reasonably have high viscosity and lower cetane number. At lower load CO emissions were found higher for all diesel-biodiesel fuel blends at different higher injection pressures, as shown in

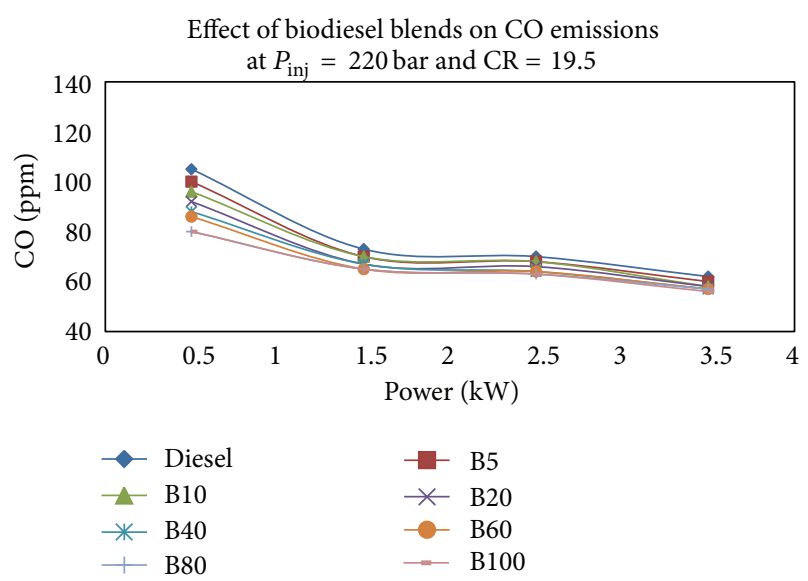

FIgURE 22: Variation in CO for various biodiesel blends at $P_{\text {inj }}$ 220 bar and CR 19.5 .

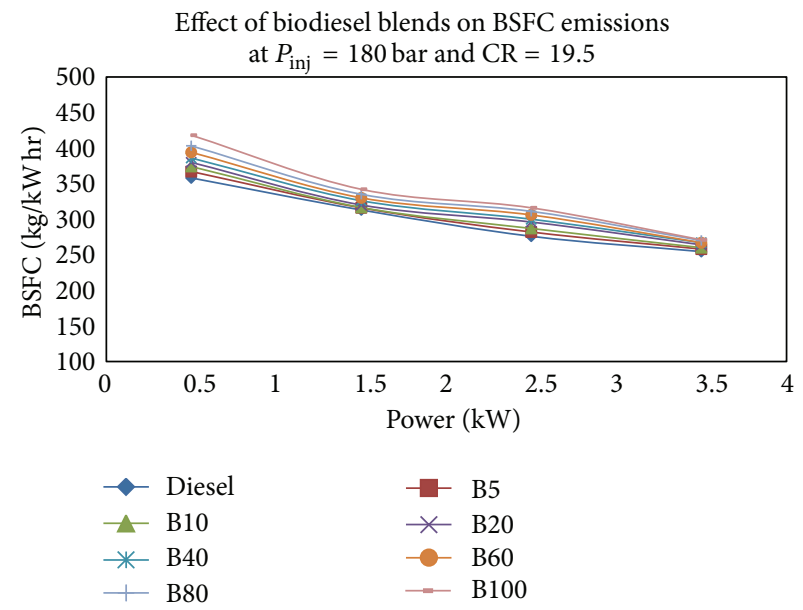

FIGURE 23: Variation in BSFC for various biodiesel blends at $P_{\text {inj }}$ 180 bar and CR 19.5 .

figure. This may be due to incomplete combustion at lower loads. For diesel, CO emissions increased from 7.1\% to $11.4 \%$ when operated at $180 \mathrm{bar}, 200 \mathrm{bar}$, and $220 \mathrm{bar}$ injection pressures. Similarly CO emission increased from $7.25 \%$ to $34.88 \%$ when operated from 180 bar to 220 bar injection pressure for various biodiesel blends.

6.2.3. BSFC. Figures 23, 24, and 25 illustrate the variation of BSFC with different IOPs of neat diesel and at various biodiesel blends fuel over entire operating range of speed $1500 \mathrm{rpm}$. Diesel-biodiesel fuel blends were tested in the engine at $180 \mathrm{bar}, 200 \mathrm{bar}$, and $220 \mathrm{bar}$ fuel injection pressures. BSFC for biodiesel-diesel blends is higher than that of diesel at a particular injection pressure. This is due to the fact that biodiesel has lower heating value compared to diesel, so more biodiesel is needed to maintain constant power output. It can be seen that at higher injection pressure BSFC goes on decreasing. The BSFC for B100 fuels is higher than diesel and blend B20 fuel which was observed due to lower calorific 


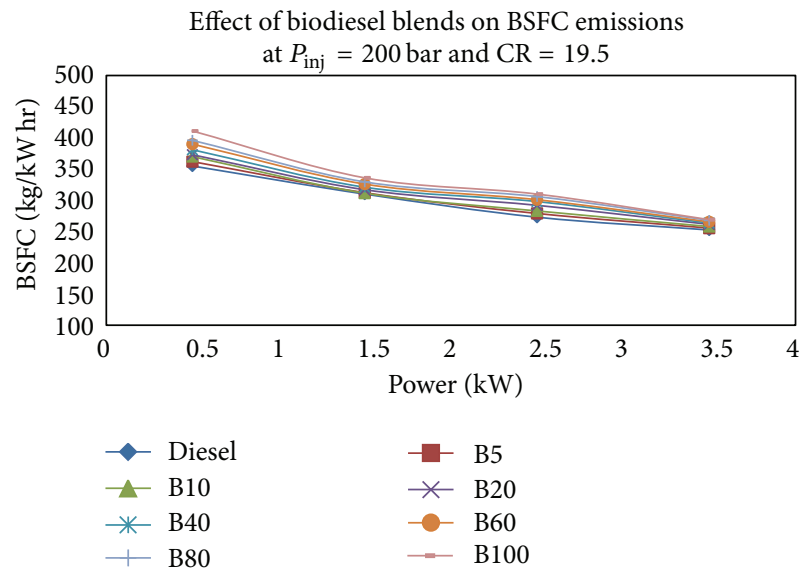

FIgURE 24: Variation in BSFC for various biodiesel blends at $P_{\text {inj }}$ 200 bar and CR 19.5 .

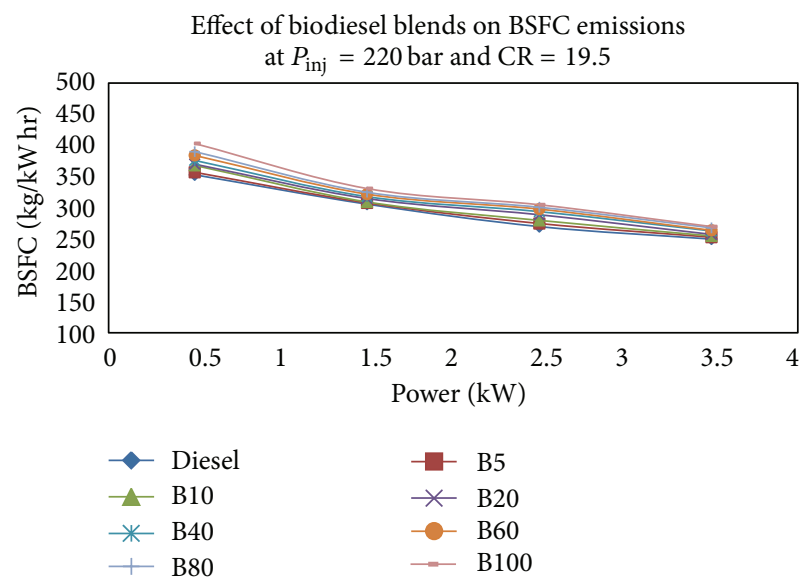

FIgURE 25: Variation in BSFC for various biodiesel blends at $P_{\text {inj }}$ 220 bar and CR 19.5 .

values, higher density, and lower energy content. Higher the density more will be the discharge of fuel for the same displacement of the plunger of the fuel injection pump. For the injector opening pressure of 200 bar with blend B20 fuel, the $\mathrm{BSFC}$ of compression ignition engine for the entire load range was lower compared to other injector opening pressures. This may be due to the increased penetration length and spray cone angle and due to more area coverage of spray formed in the combustion chamber and utilizing the air effectively resulting optimum peak pressure, better fuel air mixing, and higher spray atomization. However, injector opening pressure 220 bar, the performance has suffered significantly because of low penetration and low momentum of fuel droplets. It was observed that at retard injection timing, the BSEC of B100, B20, and diesel fuel was higher than other injection timings under all the load conditions. This may be due to poor and untimely combustion fuels. But at advance injection timing, the BSEC was lower for B20 fuel than B100 and diesel fuel. This may be due to complete combustion of fuel due to sufficient duration.

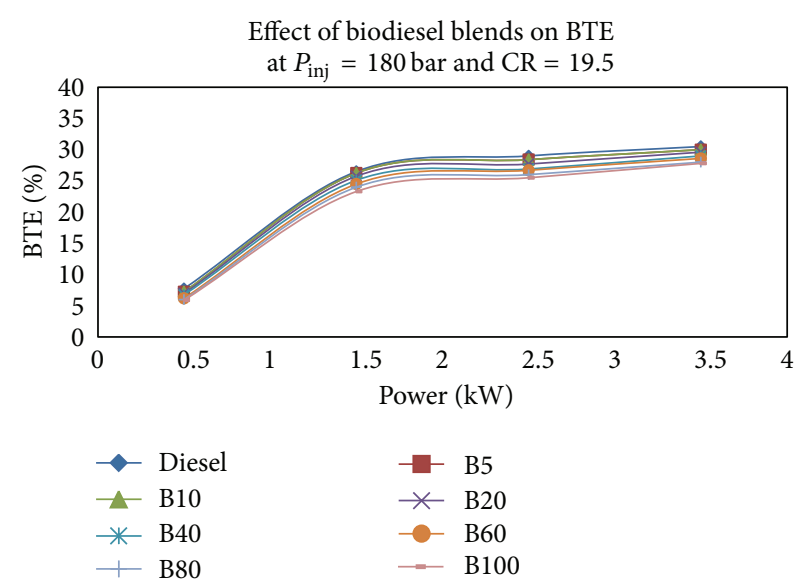

FIgURE 26: Variation in BTE for various biodiesel blends at $P_{\text {inj }}$ 180 bar and CR 19.5 .

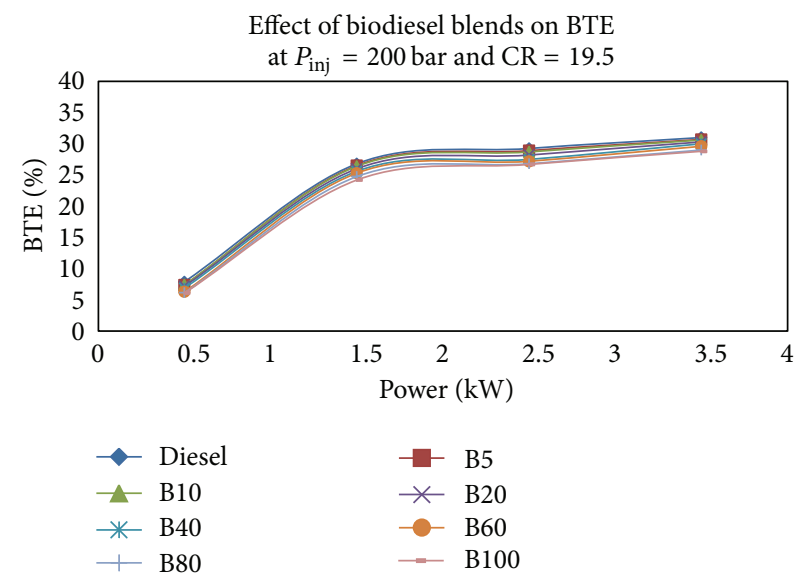

FIgURE 27: Variation in BTE for various biodiesel blends at $P_{\text {inj }}$ 200 bar and CR 19.5 .

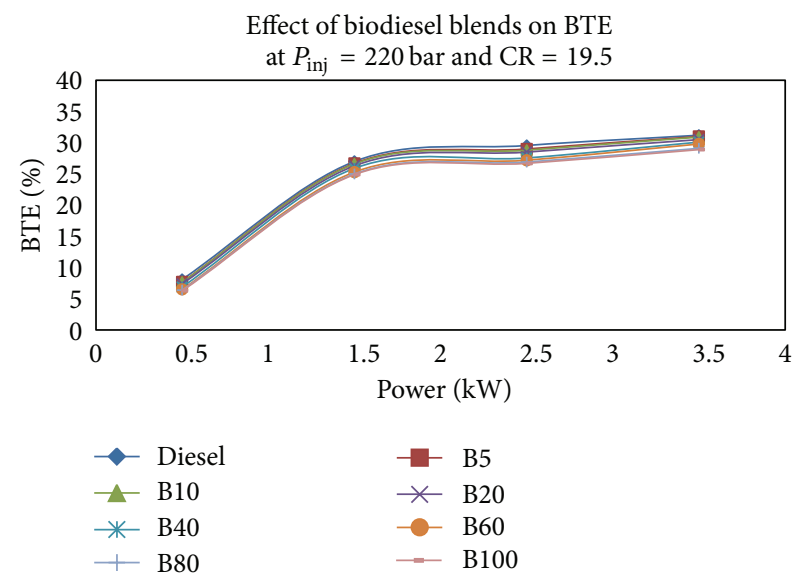

FIgURE 28: Variation in BTE for various biodiesel blends at $P_{\text {inj }}$ 180 bar and CR 19.5. 
6.3. Brake Thermal Efficiency. Figures 26, 27, and 28 illustrate the variation of brake thermal efficiency (BTE) with different IOPs with neat diesel and biodiesel blend fuel at various load points and at speed $1500 \mathrm{rpm}$. It is observed that efficiency obtained at full load and part load of blend B20 fuel with injector opening pressure 220 bar is higher than the B100 and diesel fuel compared with other injector opening pressures and similar increase in the thermal efficiency was also observed in the remaining loads. It can be observed that the thermal efficiency of all fuels at lower injection pressure is low due to coarse spray formation and poor atomization and mixture formation of biodiesel during injection. However, with higher injection opening pressure due to the fine spray formed during injection and improved atomization, resulted with lower physical delay period yielding in better combustion. This will enhance combustion and in turn improves efficiency. For blend B20 fuel, the brake thermal efficiency is markedly higher than B100 fuel and diesel fuel. The possible reason for the above findings is attributed to the additional lubricity of biodiesel which tends to minimize the frictional losses in the cylinder. The maximum BTE occurred with IOP 220 bar and blend B20 which was selected as optimal injection pressure. Further, increase in the injector opening pressure beyond 220 bar to 240 bar resulted in decrease in the thermal efficiency with all test fuels. This may be due to the fact that at higher injection opening pressure, the size of fuel droplets decreases drastically. It can be observed that the brake thermal efficiency for biodiesel is lower than diesel fuel. This is because of lower heating value and specific gravity. The combination of heating value and mass flow rate indicates energy input to the engine. This energy input or consumption to the engine in case of biodiesel is more compared to diesel. It has been also observed that as the injection pressure goes on increasing brake thermal efficiency also goes on increasing over all the range of biodiesels.

\section{Conclusions}

From the experimental investigations on use of Jatropha biodiesel blend in a single-cylinder diesel engine, the following conclusions could be drawn. Single-cylinder diesel engine requires no modification in hardware during testing. The effect of compression ratios for various blends of B5, B10, B20, B40, B60, B80, and B100 has been concluded.

(i) Improvement in BTE and BSFC was observed at higher compressions ratio 19.5 as compared to 17.5 at all blends. It showed that the higher compression ratio compensate the loss of BTE with biodiesel blends. The brake thermal efficiency was found to increase with increase in compression ratio and there is no significant difference in the brake thermal efficiency of biodiesel blends and neat diesel. However BTE increased in the range from $6.76 \%$ to $7.40 \%$ for different biodiesel blends.

(ii) Low smoke opacity was observed with higher compression ratio due to better combustion. Maximum reduction in smoke opacity was $22 \%$ at compression ratio 19.5. (iii) The CO and THC emissions decreased by 7 to $10 \%$ with CR 19.5 as compared with CR 17.5 at all biodiesel blend ratios. The biodiesel fuel has high viscosity, so due to high viscosity the air-fuel mixing process is affected by the difficulty in vaporization and atomization. The resulting rich mixtures causes incomplete combustion because of lack of oxygen content and produces higher emissions.

(iv) Diesel-biodiesel fuel blends were tested in the engine at 180 bar, 200 bar, and 220 bar fuel injection pressures. BSFC for biodiesel-diesel blends is higher than that of diesel at a particular injection pressure. This is due to the fact that biodiesel has lower heating value compared to diesel, so more biodiesel is needed to maintain constant power output. It can be seen that at higher injection pressure BSFC goes on decreasing.

(v) Continuous improvement in smoke opacity was noticed with increased blends at $P_{\text {inj }}=180$ bar. At $P_{\text {inj }}=200$ bar and $P_{\text {inj }}=220$ bar injection pressures, the reduction in smoke opacity was only 10 to $15 \%$ through the load regions as compared to neat diesel and $100 \%$ biodiesel blend, but there was an improvement at all pressure levels with increased blends. The main reason for reduction in opacity at higher blends due to increased oxygen percentage promotes the better combustion.

(vi) Higher $\mathrm{NO}_{x}$ emissions by $1.4 \%$ were observed at 220 bar as compared to 180 bar. At lower load CO emissions were found higher for all diesel-biodiesel fuel blends at different higher injection pressures. Mainly due to incomplete combustion at lower loads points with higher air fuel ratio promote cool combustion. However maximum $\mathrm{NO}_{x}$ emission increased with the mass percent of oxygen in the biodiesel.

(vii) Overall combustion characteristics for all blends were found similar to diesel at all compression ratios. Peak pressure increases with increase in compression ratios for all biodiesel blends and neat diesel. At CR 19.5, ignition delay is shorter for all biodiesel blends than neat diesel due to higher cetane number.

(viii) Biodiesel blends have more heat release rate than mineral diesel at CR 19.5. Diesel fuel shows lowest heat release rate initially and longer duration.

(ix) Peak pressure increases with increase in loads for all fuels and at all compression ratios. Blends have more peak pressure than neat diesel and at higher compression ratio and it decreases as the biodiesel percentage decreases.

(x) A practical conclusion can be drawn that all tested fuel blends can be used safely without any modification in engine. So blends of methyl esters of Jatropha oil could be used successfully.

(xi) On the whole it is concluded that Jatropha oil can be used as fuel in diesel engine directly and by blending it with diesel fuel. Use of Jatropha oil can give better performance and reduced smoke emissions. 


\section{Acronyms}

GHG: Global house warming gases

VCR: Variable compressions ratio

BTE: Brake thermal efficiency

BSFC: Brake specific fuel consumption

CO: Carbon monoxide

EGT: Exhaust gas temperature

UHC: Unburned hydrocarbons

NO: Nitrogen oxides.

\section{Acknowledgments}

This experiment has been carried out in Internal Combustion Engine Laboratory, Department of Mechanical Engineering, Smt. Kashibai Navale College of Engineering, Pune India. The authors would like to acknowledge Professor Kiran Zende, Professor Vaibhav Bansode, and Shriram Linge for their assistance in doing the experimentation.

\section{References}

[1] A. K. Agarwal and K. Rajamanoharan, "Experimental investigations of performance and emissions of Karanja oil and its blends in a single cylinder agricultural diesel engine," Applied Energy, vol. 86, no. 1, pp. 106-112, 2009.

[2] A. Srivastava and R. Prasad, "Triglycerides-based diesel fuels," Renewable \& Sustainable Energy Reviews, vol. 4, no. 2, pp. 111133, 2000.

[3] R. J. Crookes, F. Kiannejad, and M. A. A. Nazha, "Systematic assessment of combustion characteristics of biofuels and emulsions with water for use as diesel engine fuels," Energy Conversion and Management, vol. 38, no. 15-17, pp. 1785-1795, 1997.

[4] A. Faiz and P. J. Sturm, "New directions: air pollution and road traffic in developing countries," Atmospheric Environment, vol. 34, no. 27, pp. 4745-4746, 2000.

[5] A. S. Ramadhas, S. Jayaraj, and C. Muraleedharan, "Use of vegetable oils as I.C. engine fuels-a review," Renewable Energy, vol. 29, no. 5, pp. 727-742, 2004.

[6] F. K. Forson, E. K. Oduro, and E. Hammond-Donkoh, "Performance of jatropha oil blends in a diesel engine," Renewable Energy, vol. 29, no. 7, pp. 1135-1145, 2004.

[7] A. Pandhare and A. Padalkar, Use of Jatropha Oil Methyl Ester and Its Blends as an Alternative Fuel in Diesel Engine, vol. 1-3 of ASME Digital library, ICMET, London, UK, 2011.

[8] M. Canakci and J. H. Van Gerpen, "Comparison of engine performance and emissions for petroleum diesel fuel, yellow grease biodiesel, and soybean oil biodiesel," Transactions of the American Society of Agricultural Engineers, vol. 46, no. 4, pp. 937-944, 2003.

[9] S. Kalligeros, F. Zannikos, S. Stournas et al., "An investigation of using biodiesel/marine diesel blends on the performance of a stationary diesel engine," Biomass and Bioenergy, vol. 24, no. 2, pp. 141-149, 2002.

[10] A. K. Agarwal, J. Bijwe, and L. M. Das, "Effect of biodiesel utilization of wear of vital parts in compression ignition engine," Journal of Engineering for Gas Turbines and Power, vol. 125, no. 2, pp. 604-611, 2003.

[11] R. Altin, S. Çetinkaya, and H. S. Yücesu, "The Potential of using vegetable oil fuels as fuel for diesel engines," Energy Conversion and Management, vol. 42, no. 5, pp. 529-538, 2001.
[12] M. A. Kalam, M. Husnawan, and H. H. Masjuki, "Exhaust emission and combustion evaluation of coconut oil-powered indirect injection diesel engine," Renewable Energy, vol. 28, no. 15, pp. 2405-2415, 2003.

[13] H. Raheman and S. V. Ghadge, "Performance of compression ignition engine with mahua (Madhuca indica) biodiesel," Fuel, vol. 86, no. 16, pp. 2568-2573, 2007.

[14] A. S. Ramadhas, C. Muraleedharan, and S. Jayaraj, "Performance and emission evaluation of a diesel engine fueled with methyl esters of rubber seed oil," Renewable Energy, vol. 30, no. 12, pp. 1789-1800, 2005.

[15] N. Usta, "An experimental study on performance and exhaust emissions of a diesel engine fuelled with tobacco seed oil methyl ester," Energy Conversion and Management, vol. 46, no. 15-16, pp. 2373-2386, 2005.

[16] M. A. R. Sadiq Al-Baghdadi, "Effect of compression ratio, equivalence ratio and engine speed on the performance and emission characteristics of a spark ignition engine using hydrogen as a fuel," Renewable Energy, vol. 29, no. 15, pp. 2245-2260, 2004.

[17] O. Laguitton, C. Crua, T. Cowell, M. R. Heikal, and M. R. Gold, "The effect of compression ratio on exhaust emissions from a PCCI diesel engine," Energy Conversion and Management, vol. 48, no. 11, pp. 2918-2924, 2007.

[18] R. Anand, G. R. Kannan, K. Rajasekhar Reddy, and S. Velmathi, "The performance and emissions of a variable compression ratio diesel engine fuelled with bio-diesel from cotton seed oil," Journal of Engineering and Applied Sciences, vol. 4, no. 9, pp. 7287, 2009.

[19] O. M. I. Nwafor, "Effect of advanced injection timing on emission characteristics of diesel engine running on natural gas," Renewable Energy, vol. 32, no. 14, pp. 2361-2368, 2007.

[20] S. Ueki and A. Miura, "Effect of difference of high pressure fuel injection systems on exhaust emissions from HDDI diesel engine," JSAE review, vol. 20, no. 4, pp. 555-557, 1999.

[21] H. Watanabe, T. Tahara, M. Tamanouchi, and J. Iida, "Study of the effects on exhaust emissions in direct injection diesel engines: effects of fuel injection system, distillation properties and cetane number," JSAE Review, vol. 19, no. 1, pp. 21-26, 1998.

[22] K. Zeng, Z. Huang, B. Liu et al., "Combustion characteristics of a direct-injection natural gas engine under various fuel injection timings," Applied Thermal Engineering, vol. 26, no. 8-9, pp. 806813, 2006.

[23] O. M. I. Nwafor, "Emission characteristics of diesel engine running on vegetable oil with elevated fuel inlet temperature," Biomass and Bioenergy, vol. 27, no. 5, pp. 507-511, 2004.

[24] D. Agarwal and A. K. Agarwal, "Performance and emissions characteristics of Jatropha oil (preheated and blends) in a direct injection compression ignition engine," Applied Thermal Engineering, vol. 27, no. 13, pp. 2314-2323, 2007. 


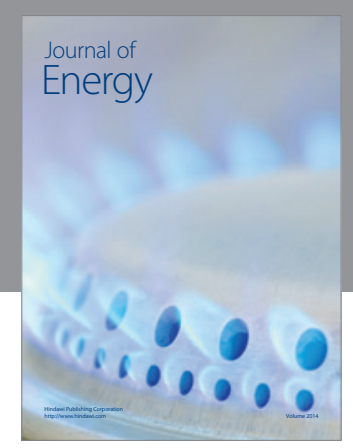

Journal of

Industrial Engineering
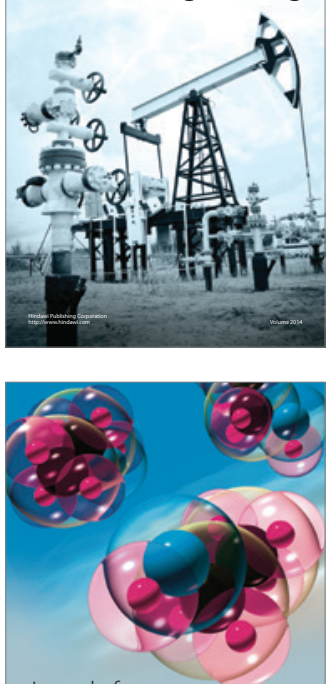

Fuels
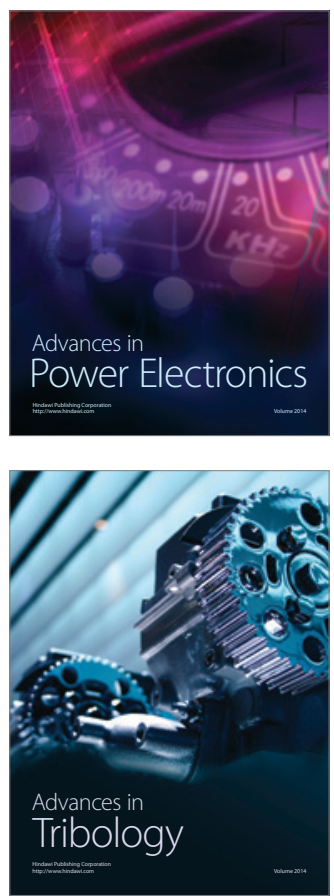

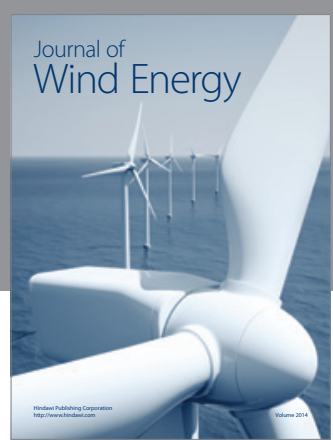

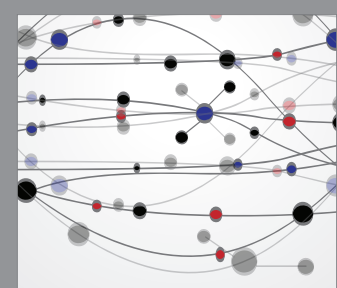

The Scientific World Journal

Submit your manuscripts at http://www.hindawi.com

Journal of

Structures
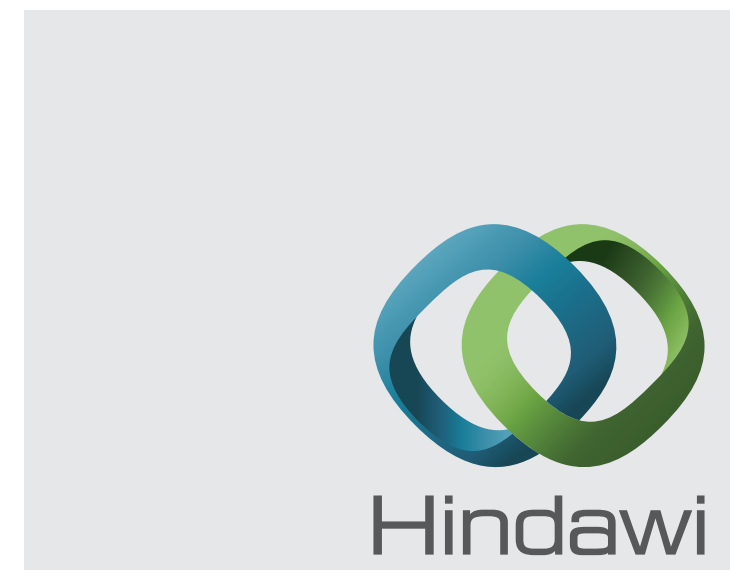

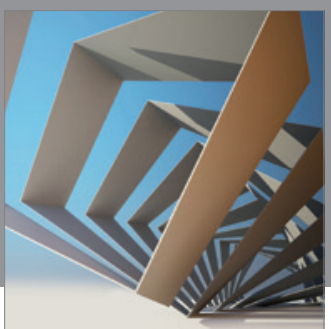

Rotating

Machinery
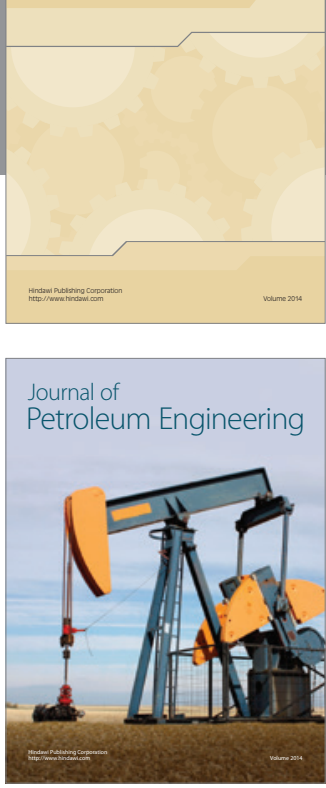

Journal of

Solar Energy
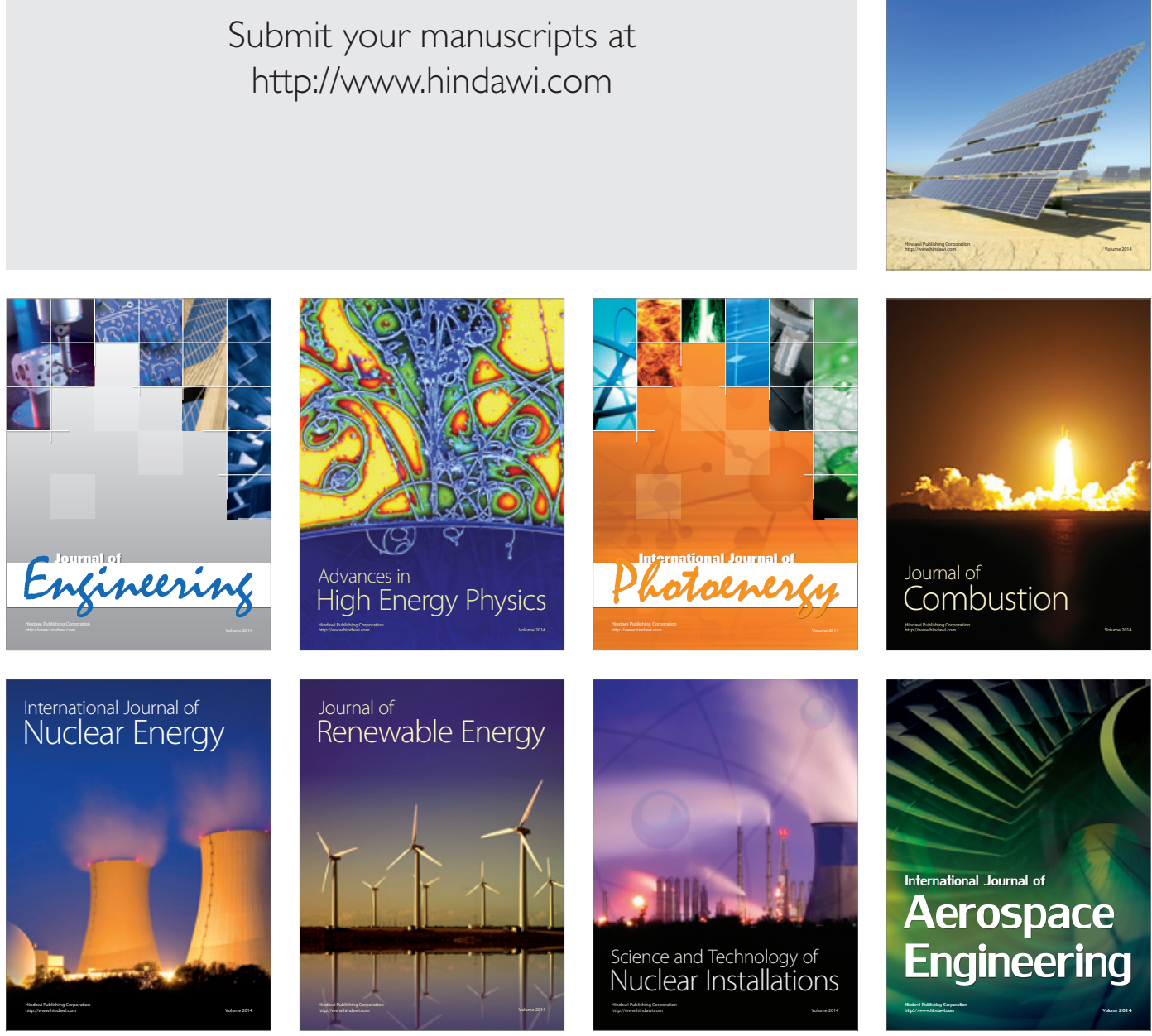